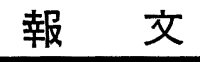

\title{
New Amphoteric Surfactants Containing a 2-Hydroxyalkyl Group. VI*
}

\author{
Alkaline Fading Rate of Triphenylmethane Dye in \\ the Presence of Amphoteric Surfactant
}

\author{
Hisao HidaKa, Hayashi Kubota, and Shuji Yoshizawa \\ Department of Chemistry, Faculty of Science and Engineering, Meisei University \\ (337, Hodokubo, Hino-shi, Tokyo)
}

\begin{abstract}
The fading rate of triphenylmethane dye, crystal violet(CV), in an alkaline solution has been measured in the presence of amphoteric surfactant micelles by following the decrease in the maximum of the visible absorption spectrum of $\mathrm{CV}$. The amphoteric surfactant used, $\mathrm{N}$-(2-hydroxydodecyl)- $\mathrm{N}-$ (2-hydroxyethyl)- $\beta$-alanine (HAA), can exist in three different forms of cationic (C-HAA), zwitter ionic $(\mathrm{Zw}-\mathrm{HAA})$, and anionic(A-HAA) types depending on $\mathrm{pH}$ value.

The fading was expressed by a pseudo-first order rate and the rate was in the order of C-HAA $>$ A-HAA $>Z_{w}-H A A$. The surface electrostatic states affected the fading rate occurring in or on micelles. The effect of addition of electrolyte was also examined and the fading was gradually accelerated with increasing concentration of electrolyte.

The ratio of $\mathrm{CV}$ solubilized in micelles to $\mathrm{CV}$ existing the outside of micelles was calculated from the fading rate curves. The solubilization of $\mathrm{CV}$ decreased with increasing electolyte concentration.
\end{abstract}

\section{Introduction}

Dye-containing micelles solution systems would be suitable for the study of models of photo= chemical energy transfer mechanism. Catalysis in micellar and macromolecular systems has been reviwed by Fendler and Fendler ${ }^{1}$. The effects of electrolyte and of structure of various surfacs tants were also examined by using an anion which was competitiveto $\mathrm{OH}^{-}$ion in the Stern layer of micelle surface. The micellar effect on an equilibrium between crystal violet $(\mathrm{CV})$ and $\mathrm{OH}^{-}$ion obeys the Hartley's "sign rule" 2 . 1Duynstee and Grundwald rerealed that the nuc= eophilic reaction between $\mathrm{CV}$ and $\mathrm{OH}^{-}$ion was accelerated in a cationic micelle system, while it was retarded in an anionic micelle system ${ }^{3,4)}$. Effects of surfactant concentration and struc= ture as well as the role of added electrolyte on the alkaline fading of $\mathrm{CV}$ have been reported by Albrizzio et $a l^{5}$.

\footnotetext{
* Previous paper; H. Hidaka, S. Yoshizawa, M.
} Takai, and M. Moriya, Yukagaku, 31, 489 (1982).
We studied the fading rate of $\mathrm{CV}$ in alkaline solution using amphoteric surfacatnt which can exist in three ionic forms, i.e. cationic, zwitter ionic, and anionic, depending on $\mathrm{pH}$ value. The characteristic of this study is that the rate can be measured for a charge-changeable surfactant without the change of the skeleton. The ef $=$ fects of the additions of electrolyte or alcohol on the fading rate were also investigated in order to examine micelle formation and bulky structure. Furthermore, an amount of $\mathrm{CV}$ sol= ubilized in micelle was calculated from the break point of the $\log \left(\mathrm{OD}_{\mathrm{t}}-\mathrm{OD}_{\infty}\right)$ versus time plots.

\section{Experimental}

\section{Materials}

The CV used was special grade (Wako Pure Chem. Ind. Co. Ltd.). The preparation and purification of HAA were the same as described in the previous paper ${ }^{6}$. HAA and equivalent $\mathrm{NaOH}$ was refluxed with stirring for $2 \mathrm{~h}$ in an alcoholic aqueous solution, followed by removal 
of the solvent to give white crystal of A-HAA. In a similar way, the cationic type (C-HAA) was obtained by adding equivalent $\mathrm{HBr}$ to $\mathrm{HAA}$ in an alcoholic aqueous solution.

\section{Measurement of Fading Rates}

Fading rate measurements were carried out spectrophotometrically with a Shimadzu Double$40 \mathrm{D}$ spectrophotometer. In a three neck Erlen= meyer flask equipped with a stirrer, which varies a revolution number in the reaction system, are placed a mixture of $10 \mathrm{ml} \mathrm{CV}$ solution $\left(3 \times 10^{-5} \mathrm{M}\right)$ and $10 \mathrm{ml}$ surfactant

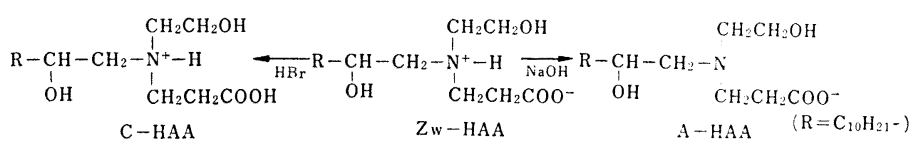

Three ionic types of HAA are expressed as follows:

of the rate constant $k=4.9 \sim 5.2 \times 10^{-4} \mathrm{~s}^{-1}$ for the same SDS-CV system, although the agita= tion condition was not mentioned in the report ${ }^{4}$. Therefore, the rate measurements for the HAA$\mathrm{CV}$ system were all carried out at $400 \mathrm{rpm}$.

\section{Results and Discussion}

solution $\left(3 \times 10^{-2} \mathrm{M}\right)$ in a thermostated bath maintained at $25^{\circ} \mathrm{C}$. The addition of an alkaline solution was followed by the disappearance of the maximum absorption peak of CV near 592 $\mathrm{nm}$. The reaction was initiated by the addition of $10 \mathrm{ml}$ of $0.3 \mathrm{~N} \mathrm{NaOH}$ solution. There is an equilibrium reaction between $\mathrm{CV}$ and $\mathrm{OH}^{-}$ion as shown in the following equation.

$$
\mathrm{C}^{+}-\left[-\underset{(\mathrm{CV})}{\mathrm{O}}-\mathrm{N}\left(\mathrm{CH}_{3}\right)_{2}\right]_{3}+\mathrm{OH}^{-}=\mathrm{HO}-\mathrm{C}-\left[-\mathrm{O}-\mathrm{N}\left(\mathrm{CH}_{3}\right)_{2}\right]_{3}
$$

The reaction can be expressed as a pseudo-first order under the condition of $\mathrm{OH}^{-}$ion $\gg \mathrm{CV}$. The optical density of $\mathrm{CV}$ absorption peak was measured at regular time intervals. The rate constant of a pseudo-first order reaction was calculated as follows:

$$
k=(1 / t) \cdot\left[\ln \left(\mathrm{OD}_{0}-\mathrm{OD}_{\infty}\right) /\left(\mathrm{OD}_{\mathrm{t}}-\mathrm{OD}_{\infty}\right)\right]
$$

where $k$ is the pseudo-first order rate constant, $t$ reaction time (s), $\mathrm{OD}_{0}$ the optical density at the starting step, $\mathrm{OD}_{\infty}$ one after the reaction time of $24 \mathrm{~h}$, and $\mathrm{OD}_{\mathrm{t}}$ one after $t$ time. In order to examine the effects of addition of elec= trolyte or alcohol, the appropriate amount of $\mathrm{NaCl}, \mathrm{NaBr}$ or $\mathrm{C}_{2} \mathrm{H}_{5} \mathrm{OH}$ was added to the above systems.

The effects of agitation on the fading rate constant were also examined. The rate constant as a function of revolution number of a stirrer for a sodium dodecyl sulfate (SDS)-CV system was measured to give the following results; 4.79 $\times 10^{-4} \mathrm{~s}^{-1}(200 \mathrm{rpm}), \quad 5.17 \times 10^{-4} \mathrm{~s}^{-1}(300 \mathrm{rpm})$, $5.20 \times 10^{-4} \mathrm{~s}^{-1}(400 \mathrm{rpm})$, and $5.00 \times 10^{-4} \mathrm{~s}^{-1}(500$ rpm), respectively. The rate constant reaches a plateau value at $400 \mathrm{rpm}$ or above, which is in good agreement with the Duynstee's results ${ }^{4}$
From the measurements of potentiometric titra $=$ tion, the isoelectric point $\mathrm{pI}$, the dissociation constants $\mathrm{pK}_{1}$ and $\mathrm{pK}_{2}$ are $6.80,5.15$, and 8.45, respectively as reported previously ${ }^{7}$. The cat $=$ ionic type holds at the range below $\mathrm{pK}_{1}$, while the anionic type is at the $\mathrm{pH}$ range above $\mathrm{pK}_{2}$. In the intermediate range between $\mathrm{pK}_{1}$ and $\mathrm{pK}_{2}$, the surfactant has zwitter ionic properties. The critical micelle concentration (cmc) of $\mathrm{ZW}_{\mathrm{w}}$ HAA was determined to be $2.2 \mathrm{mM}$ by the Wilhelmy's surface tension method ${ }^{6}$. Further, the dependence of $\mathrm{cmc}$ on $\mathrm{pH}$ value was also measured and the $\mathrm{cmc}$ of A-HAA having ${ }_{-} \mathrm{COO}^{-} \mathrm{Na}^{+}$group was lower than that of $\mathrm{C}^{-}$ HAA having $\left[-\mathrm{N}^{+} \mathrm{H}<\right] \mathrm{Br}^{-}$group ${ }^{7)}$. Since a $\mathrm{cmc}$ value is inversely proportional to an aggre= gation number from the estimation of Anacker's results $^{8), 9)}$, the aggregation number of A-HAA is presumed to be larger than that of C-HAA. The experiment of fading described in this paper was carried out in the micellar solution of $10 \mathrm{mM}$ which corresponds to about 5 times more than the cmc of $\mathrm{Z}_{\mathrm{w}}$-HAA.

Visible and ultraviolet spectra were recorded for $\mathrm{CV}$ solution with $\mathrm{C}-\mathrm{HAA}, \mathrm{Z}_{\mathrm{w}}-\mathrm{HAA}$, or AHAA, respectively. The visible spectrum of $\mathrm{CV}$ has the maximum absorption peak at 592 $\mathrm{nm}$, attributed to $n-\Pi^{*}$ transition. It was re= ported by Duynstee and Grundwald that the anionic SDS system showed a red shift for CV which is basic dye $\mathrm{e}^{3), 4)}$. In contrast, SDS showed no shift and hexadecyltrimethylammonium bro= mide (CTAB) showed a red shift for an acidic $\mathrm{dye}^{3), 4)}$. The electrostatic state was known to affect the shift of dye in micelles. With re= spect to the CV solution, A-HAA caused a red shift of $8 \mathrm{~nm}, \mathrm{Z}_{\mathrm{w}}-\mathrm{HAA}$ caused no shift, and 
C-HAA was again caused a red shift of $5 \mathrm{~nm}$. The $\lambda_{\max } 315 \mathrm{~nm}$ of $\mathrm{CV}$ attributed to $\Pi-\Pi^{*}$ transition hardly shifted in each spectrum for the solution with $\mathrm{C}-\mathrm{HAA}, \mathrm{Zw}-\mathrm{HAA}$, or AHAA. In all reactions, each optical density against reaction time was measured at the fixed wavelength of $592 \mathrm{~nm}$ which was the maximum absorption peak of $\mathrm{CV}$.

The relationship between $\log \left(\mathrm{OD}_{\mathrm{t}}-\mathrm{OD}_{\infty}\right)$ and reaction time is plotted in Fig. -1 .

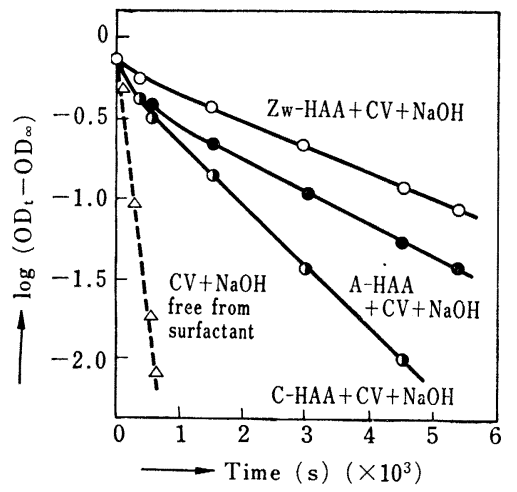

Fig.-1 Effect of the fading rate on A-HAA, $\mathrm{Zw}_{\mathrm{w}-}$ $\mathrm{HAA}$, and C-HAA micelles at $25^{\circ} \mathrm{C}$.

The fading rate decreased in the order of $\mathrm{C}$ $\mathrm{HAA}>\mathrm{A}-\mathrm{HAA}>\mathrm{Z}_{\mathrm{w}}-\mathrm{HAA}$. The $k_{\psi} / k_{0}$ ratio of $\mathrm{CV}$ fading rate was calculated, where $k_{\psi}$ and $k_{0}$ are the observed pseudo-first order rate con= stants for the attainment of equilibrium in the presence and absence of surfactant. The $k_{\psi} / k_{0}$ ratio was 0.19 for C-HAA, 0.13 for A-HAA, and 0.09 for $\mathrm{Z}_{\mathrm{w}}-\mathrm{HAA}$, respectively. For com= parison, it was cited that the ratios were 14.1 for CTAB and 0.06 for SDS as summarized in Table-1. The fading rate of $\mathrm{CV}$ in a cationic micelle system was faster than that in an anionic micelle system in regard to the effect of cationic and anionic surfactant. The anionic micelle system was slower than the system in the $a b=$ sence of surfactant from the result of Duynstee and Grunwald ${ }^{33,4)}$. However, the system in the absence of HAA exhibited the most rapid fad= ing in all systems in the presence of HAA. Since the ammonium group of CTAB is posic tively charged on the surface of micelles, the penetration of $\mathrm{OH}^{-}$ion into the charged micelle containing $\mathrm{CV}$ is achieved and hence the rate constant $k_{\psi}$ increases.

The charge of $-\mathrm{COO}^{-}$and that of $>\mathrm{NH}^{+}$- are cancelled from the consideration of surface po $=$ tential, evaluated from the titration method for a zwitter ionic surfactant ${ }^{10)}$. That is, the sur= face electrostatic potential in or on micelles is zero. (but the different point between a $z w i t=$ ter ionic surfactant system and a nonionic surf= actant one is that a gross charge of a zwitter ionic surfactant is large.) Consequently, the penetration of $\mathrm{OH}^{-}$ions into the micelles where $\mathrm{CV}$ was solubilized was lowered because of nei= ther attraction nor repulsion of electron and the fading rate decreased. However, on adding $\mathrm{Na}$ $\mathrm{OH}$ to $\mathrm{C}-\mathrm{HAA}$ or $\mathrm{Zw}$-HAA, the atmosphere of reaction field changes to alkaline side. $\mathrm{Al}=$ though C-HAA or $\mathrm{Z}_{\mathrm{w}}-\mathrm{HAA}$ is altered to AHAA, it should be allowed that the neutraliza= tion and the fading occur competitively.

When $\mathrm{CV}$ and $\mathrm{HBr}$ were added simultaneously with $\mathrm{NaOH}$, the fading rate was also measured for comparison as shown in Fig.-2. Since ex= cess $\mathrm{NaOH}$ was immediately reacted with $\mathrm{HBr}$, the fading rate was more rapid than that for the system free from the surfactant. The rea son was presumed to be due to an electrolyte

Table-1 Pseudo-first order rate constants*.

\begin{tabular}{l|c|c|c}
\hline Surfactant & Rate constant $\left(k_{\psi}, \mathrm{s}^{-1}\right)$ & $k_{\psi} / k_{0}$ ratio & References \\
\hline C-HAA & $15 \times 10^{-4}$ & 0.19 & present work \\
A-HAA & $10 \times 10^{-4}$ & 0.13 & present work \\
Zw-HAA & $7.4 \times 10^{-4}$ & 0.09 & present work \\
no surfactant & $79 \times 10^{-4}\left(k_{0}\right)$ & & present work \\
SDS & $\sim 1 \times 10^{-4 * *}$ & 0.06 & $3)$ \\
CTAB & $240 \times 10^{-4}$ & 14.1 & $3)$ \\
no detergent & $17 \times 10^{-4}\left(k_{0}\right)$ & & $3)$
\end{tabular}

* at approximately $25^{\circ} \mathrm{C}$ for the fading of $10^{-5} \mathrm{M} \mathrm{CV}$ in $10^{-2} \mathrm{M}$ surfactant solution.

** other kinetic data ${ }^{4} k_{\psi}=4.9 \sim 5.2 \times 10^{-4}$ 


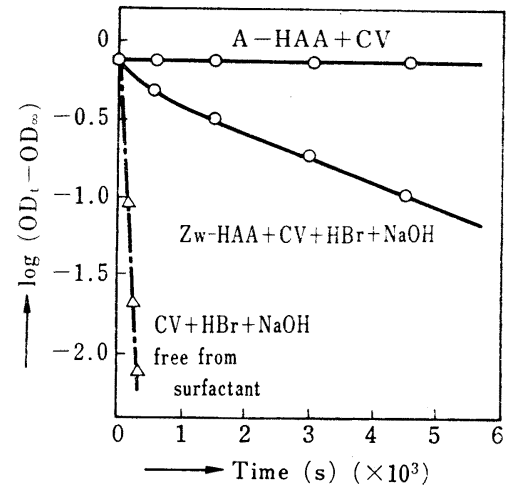

Fig.-2 Effect of reaction conditions for the fading rate at $25^{\circ} \mathrm{C}$.

effect of $\mathrm{NaBr}$ which was formed from $\mathrm{HBr}$ and $\mathrm{NaOH}$. In addition to this, the fading for the system of $\mathrm{CV}$ and A-HAA without the ad= dition of $\mathrm{NaOH}$ was very slow. When A-HAA was hydrolyzed in part to form $\mathrm{OH}^{-}$ion, $\mathrm{CV}$ was consumed. The reaction of $\mathrm{HBr}$ with $\mathrm{Na}=$ $\mathrm{OH}$ was fast when $\mathrm{CV}, \mathrm{Z}_{\mathrm{w}}-\mathrm{HAA}$, and $\mathrm{HBr}$ were simultaneously added with $\mathrm{NaOH}$. The fading rate for the above system of $\mathrm{CV}, \mathrm{ZW}_{\mathrm{w}}$ HAA, $\mathrm{NaOH}$, and $\mathrm{HBr}$ showed the same tend ency as that for $\mathrm{CV}, \mathrm{Z}_{\mathrm{w}}-\mathrm{HAA}$, and $\mathrm{NaOH}$.

The fading rates were measured immediately and at $24 \mathrm{~h}$ after $\mathrm{CV}$ was added to each HAA derivative and $\mathrm{CV}$ was solubilized in micelles. The addition time of $\mathrm{OH}^{-}$ion after the soluc bilization of $\mathrm{CV}$ in HAA micelles had no ap preciable influence on the reaction rate. This fact means that both micelle formation and sol= ubilization were very rapid.

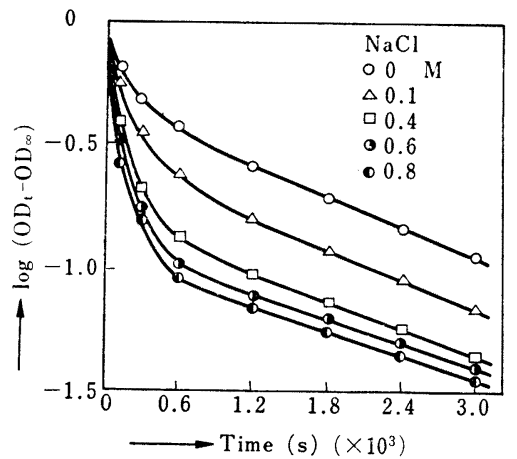

Fig.-3 Dependence of the fading rate on the addition of electrolyte $(\mathrm{NaCl})$ in or on A-HAA micelles at $25^{\circ} \mathrm{C}$.

The addition effects of electrolyte on the fads ing rate are illustrated in Fig.-3. The fading proceeds in two steps: The one is the consump= tion step of $\mathrm{CV}$ outside micelles by $\mathrm{OH}^{-}$ions and the other the comsumption one of $\mathrm{CV}$ sol= ubilized in micelles. The two steps made more clear by the addition of electrolyte. The rate of the former step was faster with the increase in the concentration of electrolyte. Subsequently, approximately $10 \mathrm{~min}$ later, the rate reached almost a plateau value. Since the slope for the $\log \left(\mathrm{OD}_{\mathrm{t}}-\mathrm{OD}_{\infty}\right)$ versus time plots is the same, the fading process of $\mathrm{CV}$ solubilized in micelles by the penetration of $\mathrm{OH}^{-}$ions has the constant rate in spite of the added amount of electrolyte. The fading rate in $\mathrm{NaBr}$ solution is almost sim= ilar to that in $\mathrm{NaCl}$ solution. The $\mathrm{cmc}$ de= creased by further addition of electrolyte as stated by Shinoda et $a l^{\cdot 11}$ We also reported the effect of electrolyte for $\mathrm{Z}_{\mathrm{w}}-\mathrm{HAA}$ as the following equation; $\log \mathrm{cmc}=-2.66-0.248 \cdot[\mathrm{C}]$ where $[\mathrm{C}]=$ molar concentration of $\mathrm{NaCl}^{6}{ }^{6}$ The relationship between $\mathrm{cmc}$ and aggregation num= ber per one micelle is in reverse proportion from the results of light scattering experimentals re= ported by Anacker et $a l^{8), 9)}$ The addition of electrolyte lets a cmc lower and anaggregation number increases. The product of aggregation number and micelles number is clearly a cono stant at a fixed concentration. Counterion ino creased with the increase in the concentration of an electrolyte so that the charge in or on the surface of micelles decreased for a GouyChapman electric double layer. Therefore, as the intermolecular force weakens, the aggrega = tion number increases and water-soluble $\mathrm{CV}$ becomes difficult to enter into the micelles. Consequently, CV of monomeric state in the outside of micelles reacts immediately with $\mathrm{OH}^{-}$ ion.

Fig. -4 shows the effects of electrolyte addi= tion on the cmc of $\mathrm{Z}_{\mathrm{w}}-\mathrm{HAA}$ and the solubili= zation percentage of $\mathrm{CV}$ for the dye used. The percentage can be calculated from the point of intersection, of which the two lines of the de= creased line in the initial step and the line in the subsequent consumpion step of $\mathrm{CV}$ solubile ized in micelles were extrapolated. Solubiliza= tion is closely related to micellization and changes in the addition of electrolytes are known to alter the $\mathrm{cmc}$ and aggregation number of the surfact= 


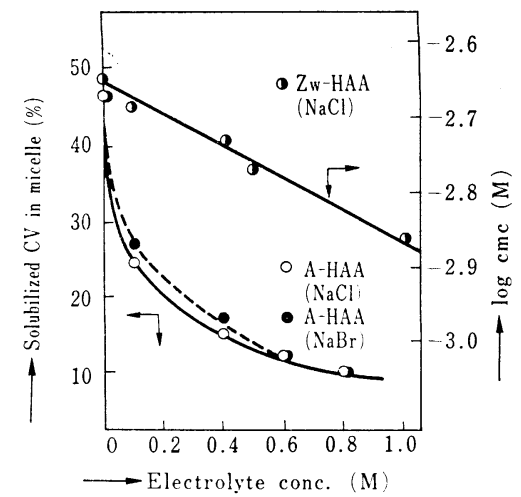

Fig.-4 Effect of $\mathrm{CV}$ solubilized in A-HAA micelles on the $\mathrm{cmc}$ for the addition of electrolyte at $25^{\circ} \mathrm{C}$.

ant as well as the solubilization. In this study, the solubilization percentage of $\mathrm{CV}$ decreased with the increase in electrolytes added. $\mathrm{Al}=$ though the solubilization percentage was $43.3 \%$ in the absence of $\mathrm{NaCl}$, the percentage fell to ca. $10 \%$ by adding $0.8 \mathrm{~mol}$ of $\mathrm{NaCl}$. Thus, $\mathrm{CV}$ became difficult to be solubilized in mis celles by adding electrolytes. The $\mathrm{cmc}$ decreased and the aggregation number inversely increased with the increase in electrolytes from the as= sumption af Anacker's results ${ }^{8), 9)}$ and Mucker= jee's data ${ }^{12)}$. If it is assumed that fixed amount of space of micelle is available for solubilization, the micelles in the presence of electrolyte would have a compacted structure of surfactants. The solubilization of $\mathrm{CV}$ was the same in both $\mathrm{Na}=$ $\mathrm{Cl}$ solution and $\mathrm{NaBr}$ solution. Consequently due to various parameters involved, solubilizas tion patterns for the CV-HAA system are dif= ficult to predict the solubilization even quali= tatively.

The effect of ethyl alcohol addition on the fading rate is shown in Fig. $\mathbf{- 5}$ The reaction rate became faster with the increase in the concentration of alcohol. The solubilization bes havior for alcohol addition is different from that for electrolyte addition. Although the addition of a small amount of alcohol have little influence on the fading rate, the reaction rate suddenly increased with further more addition of alcohol. The site of incorporation of solubilized molecules depends on the change of a spherical micelle structure by alcohol addition. Alcohol molecules would enter into micelles and hence the micelles

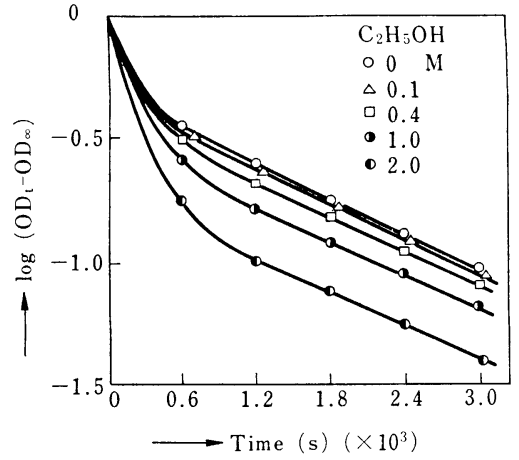

Fig.-5 Dependence of the fading rate in A-HAA micelles on the additior of ethyl alcohol at $25^{\circ} \mathrm{C}$.

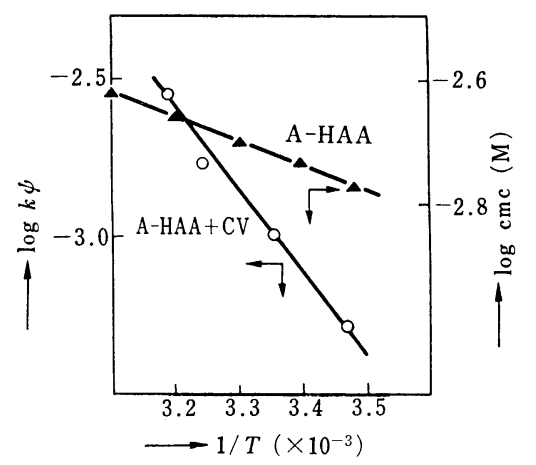

Fig. -6 Dependence of the $\mathrm{cmc}$ and the reaction rate of $\mathrm{A}-\mathrm{HAA}$ on tempetrature.

have a bulky or loosed structure.

The activation energy of the fading reaction in alkaline solution was calculated from the Arrhenius' equation; $\log k=-\Delta \mathrm{Ea} / 2.303 \mathrm{RT}$. The Ea was evaluated to be $10.9 \mathrm{kcal} / \mathrm{mol}$ for the A-HAA micelle system from the slope as shown in Fig.-6. The micelle formation energy reported in the previous paper ${ }^{7)}$ was $+1.5 \mathrm{kcal} /$ mol at $\mathrm{pH} 11$, zero at $\mathrm{pH} 6.2$, and $-2.15 \mathrm{kcal} /$ mol at $\mathrm{pH} 2$. The micelle formation energy is lower than the activation energy for alkaline fading. This fact suggests that after the mi= celles were formed, CV was solubilized and then the fading was caused.

The solubilized model of $\mathrm{CV}$ is illustrated in Fig.-7. It was assumed by Infelta $\epsilon t$ al. that the solubilisate distribution over the micelles follows Poisson's law ${ }^{13) \sim 15}$. In this paper, the location (the surface orcore of micelles) of $\mathrm{CV}$ solubilized can not be determined. The cationic type (C-HAA) system has positive 


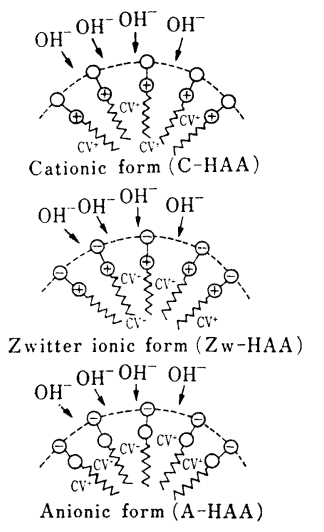

Fig. -7 Schematic repre= sentation of the CV-alkaline fad $=$ ing for A-HAA, $\mathrm{Zw}-\mathrm{HAA}$, and CHAA micelles. charges on the sur= face of micelles. The $\mathrm{OH}^{-}$ions facilitate the approach to the $\mathrm{CV}$ molecules solu= bilized in micelles and so the fading rate is fast. But, fading rate for $\mathrm{C}$ HAA is slow in como parison with the $\mathrm{C}=$ TAB system. This finding implies that the $-\mathrm{COOH}$ group on the surface of $\mathrm{mi}=$ celles prevents the attack of $\mathrm{OH}^{-}$ions.

Whereas, the ans ionic type (A-HAA)

system has negative charges on the surface of micelles. Therefore, $\mathrm{OH}^{-}$ions are difficult to approach to the CV solubilized in micelles and the rate is slow.

Since $\mathrm{Z}_{\mathrm{W}}$-HAA exhibits electrostatic stabili= zation and no effective charge, the solubility of $\mathrm{Z}_{\mathrm{w}}$-HAA for water was dropped. The $\mathrm{cmc}$ of $\mathrm{ZW}_{\mathrm{W}-\mathrm{HAA}}$ is lower than that of A-HAA or CHAA. Therefore, the hydrophobic interactions are enhanced and the aggregation number in = creased. Thus, the attack of water-soluble $\mathrm{OH}^{-}$ ions is hindered due to the hydrophobic factor. Consequently, the rate for $\mathrm{Zw}_{\mathrm{w}}-\mathrm{HAA}$ system is assumed to be the slowest. Moreover, the structural factor in regard to not only the loca= tion of amino group but also the steric hino drance of two hydroxy groups of 2-hydroxy= dodecyl and 2-hydroxyethyl groups are closely related to the fading rate.

\section{Acknowledgments}

We gratefully acknowledge Dr. M. Moriya and Dr. M. Takai for their support in this work. We would also like to thank Mr. Y. Takahashi and Mr. K. Watanabe for their technical assistance.

(Received Oct. 4, 1982)

\section{References}

1) J.H. Fendler and E.J. Fendler, "Catalysis in Micellar and Macromolecular Systems", Aca= demic Press, New York (1975) p. 198.
2) G.S. Hartley, Trans. Faraday Soc., 30, 444 (1934).

3) E.F.J. Duynstee and E. Grundwald, J. Am. Chem. Soc., 81, 4540 (1959).

4) E.F.J. Duynstee and E. Grundwald, J. Am. Chem. Soc., 81, 4542 (1959).

5) J. Albrizzio, J. Archila, T. Rodulfo, and E.H. Cordes, J. Org. Chem., 37, 871 (1972).

6) M. Takai, H. Hidaka, M. Moriya, J. Am. Oil Chem. Soc., 56, 537 (1979).

7) H. Hidaka, M. Moriya, and M. Takai, J. Am. Oil Chem. Soc., 56, 914 (1979).

8) E.W. Anacker and A.L. Underwood, J. Phys. Chem., 85, 2463 (1981).

9) E.W. Anacker and H.M. Ghose, J. Am. Chem. Soc., 90, 3161 (1968).

10) F. Tokiwa and K. Ohki, J. Phy. Chem., 71, 1824 (1967).

11) K. Shinoda, T. Yamaguchi, and R. Hori, Bull. Chem. Soc. Jpn., 34, 237 (1961).

12) P. Mukerjee, K.J. Mysels, and P. Kapauan, J. Phys. Chem., 71, 4166 (1967).

13) P.P. Infelta, M. Grätzel, and M. Thomas, $J$. Phys. Chem., 78, 1906 (1974).

14) P.P. Infelta, Chem. Phys. Lett., 61, 88 (1979).

15) P.P. Infelta and M. Grätzel, J. Chem. Phys, 70, 179 (1979).

\section{2-ヒドロキシアルキル基を有する}

新両性界面活性剂（第 6 報）

両性界面活性剤存在下でのトリフェニル

メタン色素のアルカリ退色速度に

関する研究

\section{日高久夫・窪田 快・吉沢秀二 \\ 明星大学理工学部（東京都日野市程久保 337 )}

両性界面活性片存在下で, トリフェニルメタン色素 〔クリスタルバイオレット (CV)]のアルカリ溶液中に 抢ける退色速度を $\mathrm{CV}$ 色素の可視吸収スペクトルの吸 光度 $(592 \mathrm{~nm})$ の減少から測定した。

両性界面活性剤, $N-(2-$ ヒドロキシドデシル $)-N-(2-$ ヒドロキシエチル)- $\beta$-アラニン (HAA) は $\mathrm{pH}$ 変化に より陰イオン型 (C-HAA), 両性イオン型 ( $\mathrm{Z}$ w-HAA) と陽イオン型 (A-HAA) になり, 同一骨格で荷電状態 を変化させることが可能である。

退色速度は偽一次反応で表され, 速度は C-HAA> A-HAA $>$ Zw-HAA の順に低下する。

表面電荷状態がミセル内部または表面で起きる退色速 度に影響を与える。電解質添加の影響む調べ, 添加量の 増加と共に徐々に退色速度は速くなる。

ミセル内部に可溶化した CV とミセル外部に存在す る CV 色素の割合を退色速度曲線から計算した。CVの 可溶化量は電解質濃度に伴って減少した。 